\title{
ARSENIC CONTAMINATION IN THE DEEP AND SHALLOW GROUNDWATER OF KATHMANDU VALLEY, NEPAL
}

\author{
S.M.Shrestha*, K.Rijal* and M.R. Pokhrel** \\ *Central Department of Environmental Science, Tribhuvan University, Kirtipur, Kathmandu, Nepal. \\ ** Central Department of Chemistry, Tribhuvan University, Kirtipur, Kathmandu, Nepal.
}

\begin{abstract}
A study was conducted in forty-one deep groundwater and twenty shallow groundwater wells of Kathmandu Valley, Nepal to assess arsenic contamination, spatial variation of arsenic and variation of arsenic in between deep and shallow groundwater wells. The depths of the wells were ranged from 9 to $304 \mathrm{~m}$. Groundwater samples were collected during premonsoon season in 2012. Atomic Absorption Spectrometer (AAS) was used to measure the concentration of arsenic. In deep groundwater, 34\% wells exceeded provisional guideline values of World Health Organization (WHO) of $0.01 \mathrm{mg} / \mathrm{L}$ for drinking water but all the samples of shallow groundwater wells were within the guideline values of WHO. The arsenic varies spatially with high concentration towards central groundwater district. Negative Correlation between arsenic and ORP $(r=-0.540, p<0.01)$ showed reductive arsenic mobilization mechanisms in deep groundwater. There was very weak negative correlations between arsenic concentration and depth of deep groundwater wells $(r=-0.0062, p=0.969)$. The t-test revealed significant differences in concentration of arsenic in between shallow and deep ground water at $\mathrm{p}<0.01$ with higher values of arsenic in deep groundwater.
\end{abstract}

Keywords: Arsenic; Groundwater; Oxidation reduction potential (ORP); Spatial distribution.

\section{INTRODUCTION}

Arsenic contamination of drinking water is one of the major problems in the world. Arsenic poses health risks and health problems. Arsenic is recognized as a toxic element and has been classified as a human carcinogen affecting skin and lungs. ${ }^{[1]}$ In recent past years, the occurrence of high concentrations of arsenic has been detected in groundwater from a number of regions across the world. The problem has increased greatly in recent years in several regions of Southeast Asia. In this region, countries affected with arsenic in groundwater include Bangladesh, several states of India (West Bengal, Bihar, Uttar Pradesh, Jharkhand, Assam, Chattisgarh, and Manipur), Nepal, Myanmar, Pakistan, Vietnam, Lao People's Democratic Republic, Cambodia and China. ${ }^{[2,3]}$ Arsenic contaminations of ground water also have been reported in Nepal. Arsenic concentration in the groundwater of Kathmandu Valley, Nepal is one of the major concerns while assessing groundwater quality. The provisional guideline value for arsenic in drinking water as recommended by World Health Organization (WHO) is $0.01 \mathrm{mg} / \mathrm{L} .{ }^{[4]}$ Nepal has also set National Drinking Water Quality Standard (NDWQS) of arsenic $0.05 \mathrm{mg} / \mathrm{L} .{ }^{[5]}$

The demand for water is increasing due to rapid growth of urban population and industrial activities in Kathmandu Valley. As a result there is an immense pressure on groundwater resources in the valley. The ground water is depleting due to over extraction and surface water catchments are becoming degraded. ${ }^{[6]}$ Groundwater was first exploited for water supply in 1970 in Kathmandu Valley. Mechanized extraction of groundwater resources began in earliest in 1984. In 1987, the groundwater extraction rate from Nepal Water Supply Corporation (NWSC), now called as Kathmandu Upatyaka Khanepani Limited (KUKL) since 2008, had nearly quadrupled the 1984 extraction. Groundwater is an important water resource in Kathmandu Valley. It contributes $50 \%$ of the total water supply in the valley. ${ }^{[7]}$ Though groundwater is major source of water supply knowledge on arsenic contamination in groundwater resources is limited.

Groundwater survey of Kathmandu Valley reported the presence of arsenic and the concentrations were below WHO (1993) guidelines values. ${ }^{[8]}$ A study carried out by Amatya (2002) observed that the arsenic concentration of some samples exceeded the NDWQS standards of Nepal. ${ }^{[9]}$ Similar study carried out by JICA/ENPHO (2005) revealed that the ground water resources of Kathmandu Valley are highly vulnerable to arsenic

Author for Correspondence: S.M.Shrestha, Central Department of Environmental Science, Tribhuvan University, Kirtipur, Kathmandu, Nepal. E-mail : sshrestha@cdes.edu.np. 
contamination, particularly in deep aquifers $(>200 \mathrm{~m})$ of several samples exceeded $0.200 \mathrm{mg} / \mathrm{L} .{ }^{[10]}$ Likewise, other studies have reported elevated levels of arsenic in groundwater of Kathmandu. ${ }^{[11,12,13,14,15]}$ These studies have confirmed the presence of arsenic in ground water of Kathmandu Valley. Vulnerability of arsenic in deep groundwater wells in Kathmandu Valley is a very critical issue due to its negative impact on health as a high percentage of water demand in the valley is met through ground water resources. There have been no in-depth studies concerning arsenic contamination in groundwater resources of the valley. It is therefore the aim of the study to provide benchmark information on arsenic contamination in shallow and deep groundwater resources in the valley. There is poor understanding of heavy arsenic distribution in deep groundwater of Kathmandu Valley. Therefore, the study attempted to assess spatial distribution pattern of arsenic in northern groundwater district (NGWD), central groundwater district (CGWD) and southern groundwater district (SGWD) of the Kathmandu Valley in GIS environment. This study attempted to show the relationships between depth of the groundwater wells and arsenic concentration and to compare with reported result of earlier study. Furthermore, the objective of study was also to visualize the variation of arsenic in between in deep and shallow groundwater of Kathmandu Valley.

\section{MATERIALS AND METHODS}

\section{Study Area}

Kathmandu Valley covers an area of roughly $500 \mathrm{~km}^{2}$ centered on $27^{\circ} 42^{\prime} \mathrm{N}, 85^{\circ} 20^{\prime} \mathrm{E}$. It is located in the central part of Nepal (Fig. 1). The average altitude of the valley floor is about $1350 \mathrm{~m}$ above sea level and the surrounding hills are about $2800 \mathrm{~m}$ above sea level. The climate of the region is semi tropics, warm and temperate; and annual precipitation is $1639.7 \mathrm{~mm} .{ }^{[16]}$ The precipitation is dominated by monsoon rainfall, which lasts for the months of July to September and contributes $80 \%$ of annual precipitation. ${ }^{[17]}$

The Kathmandu Valley is an intermontane basin containing up to $500 \mathrm{~m}$ of a thick band of pliocenequaternary fluvio-lacustrine sediments. ${ }^{[18]}$ The deep aquifer system can be divided into three groundwater districts, i.e., northern, central and southern groundwater districts based on hydrogeological considerations. ${ }^{[17]}$ The northern groundwater district, forming the main aquifer, has the upper deposits composed of unconsolidated and highly permeable micaceous quartz, sand and gravel about $60 \mathrm{~m}$ thick, interbedded with several impermeable fine layers. The coarse sediments in the northern part of the valley represent delta deposits and facies that are influenced by the processes of delta progradation and paleo-lake fluctuation . ${ }^{[19]}$

In the central groundwater district, the upper deposits are composed of impermeable very thick stiff black clay with peat and lignite bands, named as Kalimati formation. The Kalimati formation is overlaid by fluvial originated fine to medium sand, silt intercalated clay and fine gravels. The dominance of black clay layer is barrier in groundwater recharge in the central groundwater. Unconsolidated low permeable coarse sediments underlying the clay bed constitute a confined aquifer. The urban cores of Kathmandu and Lalitpur district are located in this central groundwater district. The southern groundwater district is characterized

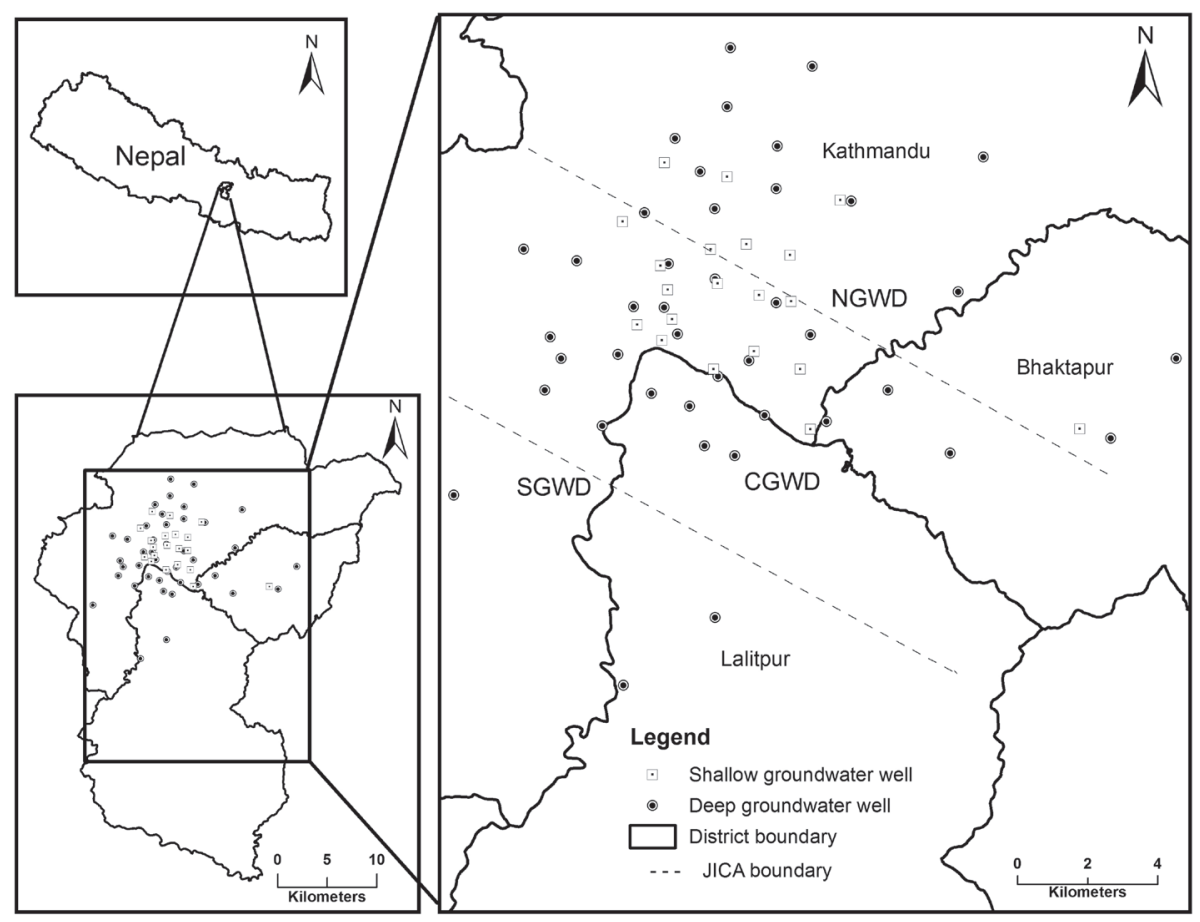

Fig. 1: Location map of the study area (Kathmandu Valley) and sampling locations 
by a thick impermeable clay and basal gravel of low permeability and parts of the district (eastern area of the southern groundwater district) are covered with sand and gravel deposits which are potential for groundwater recharge. ${ }^{[17,19,20]}$ The aquifers in the Kathmandu Basin can be divided into shallow and deep systems. Shallow aquifers typically extend from less than 5 to $60 \mathrm{~m}$, and deeper aquifers lie below $60 \mathrm{~m} .{ }^{[21]}$

\section{Water sampling and analysis}

The study was carried out in sixty-one groundwater wells (deep and shallow) of Kathmandu Valley (Fig.1). The study covered the groundwater wells of 9-304 m depth. The geo-positions of groundwater sampling locations were determined using global positioning systems (GPS). Random sampling technique was used to collect groundwater samples. The water samples were taken in premonsoon (month of April-May 2012). A set of samples were collected in the sampling bottles after pumping water for five minutes before sampling to get the representative sample of the groundwater well. The bottles were labeled with the sample code number. Those samples were then brought to the laboratory for analysis. The samples were preserved immediately after sampling by acidifying with $2 \mathrm{~mL} / \mathrm{L}$ concentrated nitric acid $\left(\mathrm{HNO}_{3}\right)$ as per APHA-AWWA-WEF 2006. ${ }^{[22]}$ The samples were kept at $4{ }^{\circ} \mathrm{C}$ prior to analysis. The analysis of arsenic was carried out in Nepal standard (NS) certified CEMAT Water Laboratory by using Varian AA 240 atomic absorption spectrometer (Australia) with vapor generation accessory VGA-77 (Australia) as per the APHA-AWWA-WEF 2006. ${ }^{[22]}$ The accuracy of determination of arsenic in water was ensured by using standard solution produced by Merck, Germany traceable to standard reference material (SRM) of NIST (National Institute of Standards and Technology, Gaithersburg, MD, USA). EC, ORP, pH and temperature were measured in situ at each sampling location. The $\mathrm{pH}$ and ORP were measured by Hanna HI 8314 pH/ ORP meter (Italy). EC was measured by Jenway 4200 conductivity meter (UK). Microsoft Office Excel (2007) and SPSS version 18 were used for statistical analysis.

\section{Geographic information system (GIS) and spatial analysis}

Nepal adopted universal transverse mercator (UTM) projection for the base mapping of the country with some modifications suited to its shape. This is named as modified universal transverse mercator projection. So, all the spatial data layers were maintained in a standard Nepalese coordinate system of modified universal transverse mercator, central meridian $84^{\circ}$ longitude (i.e., MUTM84). The software used for mapping and spatial analysis was ArcGIS version 9.3.

\section{RESULT AND DISCUSSION}

\section{Arsenic, pH, EC and ORP in shallow and deep groundwater wells}

The summary of $\mathrm{pH}, \mathrm{EC}, \mathrm{ORP}$ and arsenic concentration in shallow and deep groundwater wells are presented in Table 1 . The $\mathrm{pH}$ were nearly neutral that ranges from 6.1 to 7.0 in shallow groundwater well and 6.4 to 7.9 in deep groundwater well.

EC varied widely, ranging from $100 \mu \mathrm{S} / \mathrm{cm}$ to $1719 \mu \mathrm{S} /$ $\mathrm{cm}$ in deep ground water well and $200 \mu \mathrm{S} / \mathrm{cm}$ to 1202 $\mu \mathrm{S} / \mathrm{cm}$ in shallow ground water well. The mean value for EC were $639 \mu \mathrm{S} / \mathrm{cm}$ and $587 \mu \mathrm{S} / \mathrm{cm}$, respectively in deep groundwater well and shallow groundwater well. ORP value ranged from $-108 \mathrm{mV}$ to $129 \mathrm{mV}$ in shallow groundwater well and $-190 \mathrm{mV}$ to $125 \mathrm{mV}$ in deep groundwater well. Thirty-six deep groundwater wells (i.e., 88\%) showed negative ORP value, which is attributed to the reducing condition of the deep groundwater. Arsenic concentration ranged from $<0.003 \mathrm{mg} / \mathrm{L}$ to $0.005 \mathrm{mg} / \mathrm{L}$ in shallow groundwater well and $<0.003 \mathrm{mg} / \mathrm{L}$ to $0.143 \mathrm{mg} / \mathrm{L}$ in deep ground water well. The study displayed clear redox gradient between shallow and deep aquifers as indicated by the diminishing trend of ORP downward from shallow to deeper depth. Thirty-six deep groundwater wells (i.e., $88 \%$ ) showed negative ORP value.

The t-test revealed that there is significant difference in arsenic concentration in between shallow and deep groundwater wells at $\mathrm{p}<0.01$. The higher concentration of arsenic in deep groundwater wells are probably of geogenic origin and could be related to the hydrogeological activities that could be due to the reducing environment in deep groundwater of the Kathmandu Valley. The mean value of ORP in deep groundwater and shallow groundwater were $-73.5 \mathrm{mV}$ and $-29.5 \mathrm{mV}$, respectively (Table 1 ). So, shallow groundwater in the valley is less reducing in comparison with deep groundwater in Kathmandu Valley. The low concentration of arsenic in the shallow groundwater wells may be due to the more oxidized environment in shallow groundwater. The oxidized state of shallow aquifers is maintained in groundwater due to diffusion of oxygen from the atmosphere.

\section{Evaluation of arsenic with WHO guideline value and NDWQS value}

The concentrations of arsenic were compared with WHO guideline value for drinking water and NDWQS standard of Nepal. In deep groundwater, 34\% of samples of exceeded WHO provisional guideline value for drinking water of $0.01 \mathrm{mg} / \mathrm{L} .{ }^{[4]}$ and all the samples in shallow groundwater were within the guideline value. Likewise, $4.9 \%$ of deep groundwater exceeded NDWQS standard value of $0.05 \mathrm{mg} / \mathrm{L}$ for drinking water and all the samples in shallow groundwater were within the standard value. ${ }^{[5]}$ 
Table 1: Summary of statistical data for pH, EC, ORP and arsenic in shallow and deep groundwater wells

\begin{tabular}{|c|c|c|c|c|c|c|c|c|c|c|c|}
\hline \multicolumn{2}{|c|}{ Variable Unit } & \multicolumn{5}{|c|}{ Shallow groundwater wells $(n=20)$} & \multicolumn{5}{|c|}{ Deep groundwater wells $(n=41)$} \\
\hline & & Mean & Med. & Min. & Max. & $S D$ & Mean & Med. & Min. & $\operatorname{Max}$ & $S D$ \\
\hline$\overline{\text { Depth }}$ & $m$ & 20.9 & 17 & 9.1 & 39.6 & 10.14 & 222.0 & 247 & 84 & 304 & 63.8 \\
\hline$p H$ & & 6.6 & 6.7 & 6.1 & 7.0 & 0.3 & 6.7 & 6.7 & 6.4 & 7.9 & 0.3 \\
\hline$E C$ & $\mu \mathrm{S} / \mathrm{cm}$ & 639 & 554 & 200 & 1202 & 307 & 587 & 554 & 100 & 1719 & 420 \\
\hline$O R P$ & $m V$ & -29.5 & -43.5 & -108 & 129 & 61.35 & -75.3 & -95 & -190 & 125 & 69.7 \\
\hline As & $m g / L$ & $<0.003$ & $<0.003$ & $<0.003$ & 0.005 & 0.001 & 0.013 & $<0.003$ & $<0.003$ & 0.143 & 0.024 \\
\hline
\end{tabular}

Med. median, Min. minimum, Max. maximum, SD standard deviation

\section{Correlation between arsenic and depth of the deep groundwater}

The depth of the deep groundwater wells tested arsenic ranged from 84 to $304 \mathrm{~m}$. The mean and standard deviation (SD) of depth were $222.0 \mathrm{~m}$ and $63.8 \mathrm{~m}$ respectively. The study showed weak negative correlation between arsenic concentration and depth of deep groundwater wells $(r=-0.0062, p=0.969)$. Though, it showed negative correlations; p-value suggests that there is an insignificant negative correlation between arsenic concentration and depth of deep groundwater wells. It contradicts with the results shown by the studies carried out by JICA/ENPHO (2005) and Maharjan et al. (2006). ${ }^{[10,12]}$

\section{Correlation between pH, EC, ORP and arsenic}

The relationships of the $\mathrm{pH}, \mathrm{EC}, \mathrm{ORP}$ and arsenic in deep groundwater wells were examined by Spearman's rank correlation coefficient (Table 2). EC has strong positive correlation with arsenic $(\mathrm{r}=0.522, \mathrm{p}<0.01)$ suggesting lithogenic nature of the arsenic. ORP has strong negative correlation with arsenic $(r=-0.540, p$ $<0.01$ ) which can be explained by reductive arsenic mobilization mechanisms in deep groundwater.

Arsenic has weak positive correlation with $\mathrm{pH}(\mathrm{r}=0.050$, $\mathrm{p}=0.755)$. Though, it showed positive correlations; p-value suggests that there is an insignificant positive correlation between arsenic concentration and $\mathrm{pH}$ in deep groundwater.

Table 2: Spearman's rank correlation of $\mathrm{pH}, \mathrm{EC}$, ORP and arsenic in deep groundwater wells $(n=41)$

\begin{tabular}{lllll}
\hline Value & $\mathrm{pH}$ & $\mathrm{EC}$ & $\mathrm{ORP}$ & Arsenic \\
\hline $\mathrm{pH}$ & 1.000 & & & \\
$\mathrm{EC}$ & -0.229 & 1.000 & & \\
ORP & 0.024 & $-0.550^{\star *}$ & 1.000 & \\
Arsenic & 0.050 & $0.522^{* *}$ & $-0.540^{\star *}$ & 1.000
\end{tabular}

${ }^{* *}$ Significant value at $\mathrm{p}<0.01$

\section{Distribution of arsenic in deep groundwater}

The concentration of arsenic varied significantly in central, northern and southern groundwater districts of Kathmandu Valley. The spatial distribution of arsenic reveals higher values arsenic in central groundwater district. The northern and southern groundwater districts have lower arsenic concentrations in most of the deep groundwater wells The concentration of the arsenic in groundwater of the study area increases from northern to southern and showing higher towards central ground water district (Fig 2a). Similarly, spatial distribution of EC indicated progressive increase in its value from northern to southern and displaying higher in central groundwater district. Most of the deep groundwater of northern and southern groundwater districts observed low EC value (Fig. 2c). The spatial distribution of ORP in deep groundwater clearly shows most of the groundwater wells have negative ORP value (Fig. 2b). The study carried out by Khatiwada et al. (2002) found that deep aquifers in Kathmandu Basin are more reducing and reported negative ORP value up to $-195 \mathrm{mV}$ in deep aquifers indicating highly reduced environment. ${ }^{[1]}$

Groundwater quality depends on the composition of recharging water, the mineralogy and reactivity of the geological formations in aquifers, the impact of human activities and environmental parameters that may affect the geochemical mobility of certain constituents. ${ }^{[23]}$ The overall concentration of major oxides $\left(\mathrm{Fe}_{2} \mathrm{O}_{3}, \mathrm{TiO}_{2}, \mathrm{CaO}\right.$, $\mathrm{P}_{2} \mathrm{O}_{5}$ ) and trace elements ( $\mathrm{As}, \mathrm{Pb}, \mathrm{Zn}, \mathrm{Cu}, \mathrm{Ni}, \mathrm{Cr}, \mathrm{V}, \mathrm{Sr}$, $\mathrm{Y}, \mathrm{Nb}, \mathrm{Zr}, \mathrm{Th}$, and $\mathrm{Sc}$ ) of the sediments of Kathmandu Valley are not exceptional, and are similar to modern unconsolidated sediments. Overall concentrations increase toward the center from the northern marginal parts.

The variations of elemental concentration are mainly clay-controlled in both the margin and central parts. There is progressive increase in the finer particles and trace elements towards the central part of the sediments from the northern part in the valley. ${ }^{[21]}$ Therefore, higher arsenic concentration is associated with the fine grained sediments in the central groundwater district. Moreover, larger particles in sediments have less surface area available for metal hydroxide coatings to 

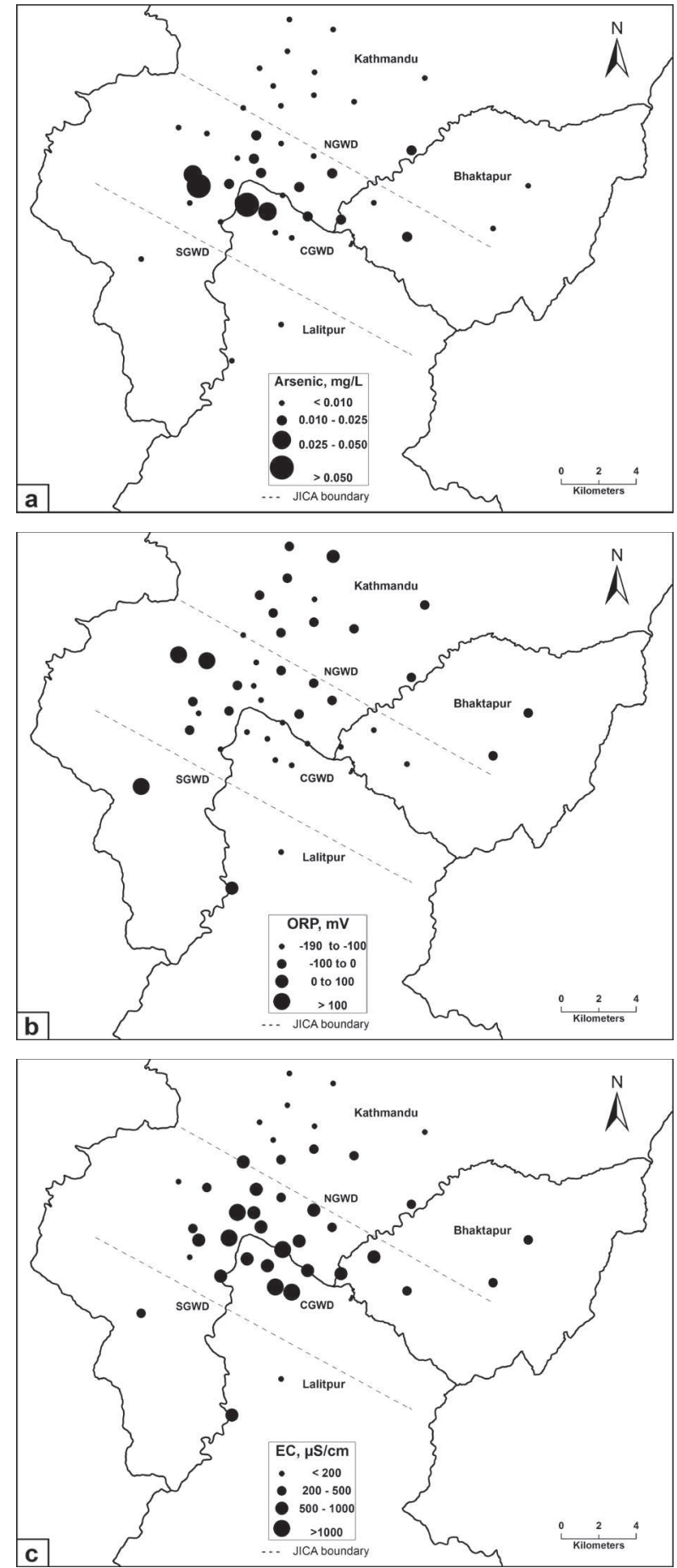

Fig. 2: Spatial distribution: (a) arsenic, (b) ORP and (c) EC in deep groundwater

form and adsorb arsenic. Less adsorbed arsenic yields a smaller amount of aqueous arsenic in equilibrium with adsorbed arsenic and results in less potential for mobilization of arsenic at concentrations of concern via reductive mobilization mechanisms. ${ }^{[24]}$ Additionally, the difference in the levels of arsenic in central and northern groundwater district might be due to the fact that the central ground water district is considered as poorly recharging due to the presence of a thick black clay layer whereas the northern groundwater district is regarded as the major recharge area in the valley. ${ }^{[17]}$ Arsenic concentrations in the Kathmandu Valley groundwaters show a large range in deep groundwater, although some of groundwater sources investigated were found to be in elevated levels in some parts of the valley could be due to the nature of the sediments there. The high degree of spatial variability in groundwater chemistry over short distances and vertical variations in groundwater chemistry observed suggests that groundwater movement has been restricted and the groundwaters are poorly mixed. ${ }^{[25]}$

Arsenic concentrations in the sediments of Kathmandu Valley averaged $8 \mathrm{mg} / \mathrm{kg}$ (ranging 3-25 mg/kg) similar to the general level seen in modern unconsolidated sediments, typically $5-10 \mathrm{mg} / \mathrm{kg}$. ${ }^{[21,26]}$ The widespread lacustrine clay of the Kathmandu Valley could have greater potentiality for arsenic release. ${ }^{[21]}$ Arsenic mobilization is high in the reducing conditions. [27, 26, 28] Microorganisms are responsible for catalyzing the oxidation of organic matter coupled to variety of electron acceptors just as microorganisms do in the surface sediments but at much slower rates ${ }^{[29]}$ which could also lead to favorable environment for arsenic release. The higher concentration of arsenic under reduced groundwater environment may be due to $\mathrm{Fe} /$ $\mathrm{Mn}$ oxides and direct reduction of $\mathrm{As}(\mathrm{V})$ into $\mathrm{As}(\mathrm{III})$. After an initial increase, arsenic concentration often decreases again as a function of time below water table due to sulfide precipitation, whereas it increases with increasing sulfate concentrations above water table. [30] Under moderately reduced environment (0-100 $\mathrm{mV}$ ), arsenic solubility seemed to be controlled by the dissolution of iron oxyhydroxides; however, at highly reduced condition, e.g., at $-250 \mathrm{mV}$, arsenic chemistry is dominated by the formation of insoluble sulfides $\mathrm{FeAsS}, \mathrm{AsS}, \mathrm{As}_{2} \mathrm{~S}_{3} .{ }^{[27]}$ Therefore, in the very deeper groundwater of Kathmandu Valley probably $>300 \mathrm{~m}$, the arsenic solubility perhaps limited by the formation of insoluble arsenic sulfide minerals. Therefore, it is suggested for more studies of change in redox gradient and change in the arsenic concentration in the groundwater of Kathmandu Valley.

\section{CONCLUSION}

This study has confirmed the presence of higher levels of arsenic in deep groundwater of Kathmandu Valley. The highest arsenic concentration measured in deep groundwater was $0.143 \mathrm{mg} / \mathrm{L}$. In deep groundwater, $34 \%$ samples exceeded provisional guideline values of WHO of $0.01 \mathrm{mg} / \mathrm{L}$ for drinking water but all the samples of shallow groundwater were within the guideline value. The arsenic varies spatially with high concentration towards central groundwater district. Strong negative correlation between arsenic and ORP confirmed reductive arsenic mobilization mechanisms in deep groundwater. The study revealed very weak negative correlation between arsenic concentration and depth of deep groundwater. Arsenic concentration varied significantly between shallow and deep groundwater. The high concentration of arsenic in deep groundwater 
of some parts of study area particularly in central groundwater district is attributed to the groundwater geochemistry in the study area. Release of arsenic into the groundwater is mainly due to the natural source under the reductive process.

\section{ACKNOWLEDEMENT}

The authors would like to express gratitude to Central Department of Environmental Science, Tribhuvan University, Nepal for the support of this research work. Authors highly acknowledge University Grants Commission, Nepal for a research grant. Thanks also due to CEMAT Water Laboratory, Kathmandu for providing laboratory facility in the analysis of heavy metals using atomic absorption spectrometer (AAS).

\section{REFERENCES}

1. IARC 2004. IARC monographs on arsenic in drinking water. International Agency for Research on Cancer. Vol 84. Lyons, France.

2. Mukherjee, A., Sengupta, M. K., Hossain, M. A., Ahamed, S., Das, B., Nayak, B., Lodh, D., Rahman, M.M. and Chakraborti, D. 2006. Arsenic contamination in groundwater: a global perspective with emphasis on the Asian scenario. Journal of Health, Population and Nutrition. 24(2): 142-163.

3. Hossain, M.F. 2006. Arsenic contamination in Bangladeshan overview. Agriculture Ecosystems and Environment. 113: $1-16$.

4. WHO 2008. Guidelines for drinking-water quality. 3rd edition vol.1. World Health Organization, Geneva.

5. GoN/MPP 2006. National Drinking Water Quality Standards. In: Nepal Gazette (B.S. 2063/03/12).Government of Nepal/ Ministry of Physical Planning, Kathmandu, Nepal.

6. ADB/KUKL 2010. Kathmandu Valley water supply and wastewater system improvement. Project feasibility study report. Asian Development Bank/Kathmandu Upatyaka Khanepani Limited, Kathmandu, Nepal.

7. AI 2004. Optimizing water use in Kathmandu Valley (ADBTA) project. Final report. Acres International in association with Arcadis Euroconsult Land and Water Product Management Group, East Consult (P) Ltd. and Water Asia (P) Ltd.

8. Jha, M.G., Khadka, M.S., Shrestha, M.P., Regmi, S., Bauld, J. and Jacobson, G. 1997. The assessment of groundwater pollution in Kathmandu, Nepal. Report on joint Nepal-Australia Project, 1995-96. Australian Geological Survey Organization.

9. Amaya, A. 2002. Arsenic in Groundwater of Alluvial Aquifers in Nepal, Extent of Contamination, Genesis and Aspects of Remediation in the Districts of Nawalparasi and Kathmandu. Master's Dissertation. TRITA-LWR, Department Land and Water Resource Engineering, Stockholm.

10. JICA/ENPHO 2005. Arsenic vulnerability in groundwater resources in Kathmandu Valley. Final Report. Japan International Cooperation Agency/Environment and Public Health Organization.

11. Khatiwada, N. R., Takizawa, S., Tran, T. V. N. and Inoue, M. 2002. Groundwater contamination assessment for sustainable water supply in Kathmandu Valley, Nepal. Water Science Technology. 46(9): 147-154.

12. Maharjan, M., Shrestha, B.R., Shrestha, K.B., Shrestha, R.R., Raut-Khadka, R., Shrestha, S.D., Kafle, B. and Ishihara, H. 2006. Arsenic contamination in groundwater resources in Kathmandu Valley. Paper presented at the 4th International Symposium on Southeast Asian Water Environment, Bangkok.

13. Chapagain, S.K., Shrestha, S., Nakamura, T., Pandey, V.P. and Kazama, F. 2009. Arsenic occurrence in groundwater of Kathmandu Valley, Nepal. Desalination and Water Treatment. 4: 248-254.

14. Shrestha, S.M., Dhakal, P., Khadka, M. and Shrestha, S. 2010. Status of arsenic in groundwater of Kathmandu Valley, Nepal. In: Proceedings of the First National Youth Conference on Environment (June 3-4, 2010), Kathmandu. Himalayan Alliance for Climate Change, Kathmandu, Nepal.

15. Chapagain, S.K., Pandey, V.P., Shrestha, S., Nakamura, T. and Kazama, F. 2010, Assessment of deep groundwater quality in Kathmandu Valley using multivariate statistical techniques. Water Air Soil Pollution. 210: 277-288.

16. CBS 2008. Environment Statistics of Nepal 2008. Central Bureau of Statistics, Kathmandu, Nepal.

17. JICA 1990. Groundwater management project in the Kathmandu Valley. Final report to Nepal Water Supply Corporation. Japan International Cooperation Agency, Kathmandu, Nepal.

18. Yoshida, M. and Igarashi, Y. 1984. Neogene to quaternary lacustrine sediment in the Kathmandu Valley, Nepal. Journal of Nepal Geological Society. 4: 73-100.

19. Sakai, T. 2001. Small amplitude lake-level fluctuations recorded in aggrading deltaic of the upper Pleistocene Thimi and Gokarna formations, Kathmandu Valley, Nepal. Journal of Nepal Geological Society. 25: 43-52.

20. Dixit, A. and Upadhya, M. 2005. Augmenting Groundwater in Kathmandu Valley: challenges and possibilities. Report to Nepal Water Conservation Foundation, Kathmandu, Nepal.

21. Gurung, J.K., Ishiga, H., Khadka, M.S. and Shrestha, N.R. 2007. The geochemical study of fluvio-lacustrine aquifers in the Kathmandu Basin (Nepal) and the implications for mobilization of arsenic. Environmental Geology. 52: 503-517.

22. APHA/AWWA/WEF 2006. Standard Methods for the Examination of Water and Wastewater. American Public Health Association, American Water Works Association, Water Environment Federation, Washington D.C., USA.

23. Kouras, A., Katsoyiannis, I. and Voutsa, D. 2007. Distribution of arsenic in groundwater in the area of Chalkidiki, Northern Greece. Journal of Hazardous Materials. 147(3): 890-899.

24. Erickson, M.L. and Barnes, R. J. 2005. Well characteristics influencing arsenic concentrations in groundwater. Water Research. 39: 4029-4039.

25. Smedley, P.L., Nicolli, H.B., MacDonald, D.M.J., Baros, A.J. and Tullio, J.O. 2002. Hydrogeochemistry of arsenic and other inorganic constituents in groundwaters from La Pampa, Argentina. Applied Geochemistry. 17: 259-284.

26. Smedley, P.L. and Kinniburgh, D. G. 2002. A review of the source, behavior and distribution of arsenic in natural waters. Applied Geochemistry. 17: 517-568. 
27. Carbonell-Barrachina, A.A., Jugsujinda, A., Burlo, F., Delaune, R.D. and Patrick, W. H. 1999. Arsenic chemistry in municipal sewage as affected by redox potential and $\mathrm{pH}$. Water Research. 34(1): 216-224

28. McArthur, J.M., Banerjee, D.M., Hudson-Edwards, K.A., Mishra, R., Purohit, R., Ravenscroft, P., Cronin, A., Howarth, R.J., Chatterjee, A., Talukder, T., Lowry D., Houghton, S. and Chada, D.K. 2004. Natural organic matter in sedimentary basins and its relation to arsenic in anoxic groundwater: the example of West Bengal and its worldwide implications. Applied Geochemistry. 19:1255-1293.
29. Lovley, D. R. and Chapelle, F.H. 1995. Deep subsurface microbial processes. Reviews of Geophysics. 33(3): 365-381.

30. Du Laing, G., Chapagain, S.K., Dewispelaere, M., Meers, E., Kazama, F., Tack, F. M. G., Rinklebe, J. and Verloo, M. G. 2009. Presence and mobility of arsenic in estuarine wetland soils of the Scheldt estuary (Belgium). Journal of Environmental Monitoring. 11: 873-881. 